\title{
Silica-scaled chrysophytes of Lake Baikal
}

\author{
A.Yu. Bessudova, V.M. Domysheva, A.D. Firsova, Y.V. Likhoshway \\ Limnological Institute, Siberian Branch, \\ Russian Academy of Sciences, Irkutsk, 664003 Russia \\ annabessudova@mail.ru, hydrochem@lin.irk.ru,adfir71@yandex.ru,likhoshway@mail.ru
}

\begin{abstract}
The list of silica-scaled chrysophytes of Lake Baikal has been enlarged using electron microscopy. It has been supplemented with 12 species and 2 forms. Spiniferomonas takahashii has been observed for the first time in the water bodies of Russia. According to our data, the list of silica-scaled chrysophytes of Lake Baikal includes 25 species and intraspecies taxa: Chrysosphaerella - 3, Paraphysomonas - 2, Clathromonas - 1, Spiniferomonas - 7, Mallomonas - 8 and Synura 4. We have also analyzed their seasonal dynamics and observed algal species that are dominant in spring, summer and autumn.
\end{abstract}

Key words: silica-scale chrysophytes; Lake Baikal

\section{Introduction}

Lake Baikal, one of the most ancient and deepest lakes in the world, is located in the belt of temperate climate, stretching from $51^{\circ} 54^{\prime} 18^{\prime \prime}$ to $51^{\circ} 54^{\prime} 30 \mathrm{~N}$ and from $126^{\circ} 37^{\prime} 12^{\prime \prime}$ to $126^{\circ} 37^{\prime} 20^{\prime \prime} \mathrm{E}$ (Baikal. Atlas, 1995). The lake is of tectonic origin and lies in the deep depression surrounded by mountain ridges. Natural conditions of the lake (Baikal. Atlas, 1995) and phytoplankton composition (Popovskaya, Genkal, Likhoshway, 2016) are not uniform because of the differences in bottom relief, shoreline and large bays.

K.I. Meyer (1930) was the first who had observed silica-scaled chrysophytes in the phytoplankton of Lake Baikal. Those were four species: Mallomonas caudata Iwanoff, M. tonsurata Teiling, Synura uvella Ehrenberg, and Chrysosphaerella Iongispina Lauterborn. Later, O.M. Kozhova (1959) also mentioned them. Then, four more species of these algae were identified in the phytoplankton of Lake Baikal: M. vannigera Asmund, Chrysospaerella conradii Bourrelly (= Chrysospaerella brevispina), C. baicalensis Popovskaya, and Paraphysomonas imperforata Lucas (Votintsev, Meshcheryakova, Popovskaya, 1975; Popovskaya, 1981; Zagorenko, Kaplina, 1988; Izmestyeva, Kozhova, 1988).

The species of the genus Mallomonas observed as M. sp. (Votintsev, Meshcheryakova, Popovskaya, 1975; Zagorenko, Kaplina, 1988; Izmestyeva, Kozhova, 1988; Vorobyeva et al., 1992) and the most common in the littoral area of the lake during the ice period (Antipova, 1969; 1974) appeared to be M. vannigera (Vorobyeva et al., 1992). It was noted that this species in Lake Baikal differed from the specimens described earlier from other water bodies (Balonov, 1980; Asmund, Kristiansen, 1986) in small size of cells, scales, spines and cysts (Vorobyeva et al., 1992).

Studies of phytoplankton by means of electron microscopy allowed the detection of 7 more silica-scaled chrysophytes: M. striata var. striata Asmund, M. alpina Pascher \& Ruttner, M. acaroides Perty, M. crassisquama (Asmund) Fott, Spiniferomonas bourrellyi Takahashi, S. trioralis f. cuspidata Balonov and P. vestita (A.C. Stokes) De Saedeleer (Vorobyeva et al., 1992). Thus, by the beginning of our investigations, 15 species and intra-species taxa of these algae have been known in Lake Baikal.

This work is aimed at revising silica-scaled chrysophytes in Lake Baikal using electron microscopy and studying their distribution depending on hydrochemical parameters of the environment. 


\section{Material and methods}

We analyzed 75 integral $(0-25 \mathrm{~m})$ water samples collected with a sampler at 25 sites in May-June and September 2016 as well as in May-June 2017 according to traditional plan (Tab. 1, Fig. 1).

Table 1. Sampling sites (see Fig. 1)

\begin{tabular}{|c|c|c|c|}
\hline $\begin{array}{c}\text { Site } \\
\text { number }\end{array}$ & Site coordinates & Region & Site \\
\hline 1. & $51^{\circ} 40,578 \mathrm{~N}, 103^{\circ} 52,309 \mathrm{E}$ & \multirow{9}{*}{$\begin{array}{c}\text { Southern } \\
\text { Baikal }\end{array}$} & 15 km off Kultuk \\
\hline 2. & $51^{\circ} 45,546 \mathrm{~N}, 104^{\circ} 13,222 \mathrm{E}$ & & $3 \mathrm{~km}$ off Marituy \\
\hline 3. & $51^{\circ} 38,710 \mathrm{~N}, 104^{\circ} 13,715 \mathrm{E}$ & & Marituy-Solzan \\
\hline 4. & $51^{\circ} 31,428 \mathrm{~N}, 104^{\circ} 14,417 \mathrm{E}$ & & $3 \mathrm{~km}$ off Solzan \\
\hline 5. & $51^{\circ} 49,033 \mathrm{~N}, 104^{\circ} 54,616 \mathrm{E}$ & & 3 km off Listvyanka \\
\hline 6. & $51^{\circ} 42,262 \mathrm{~N}, 105^{\circ} 00,720 \mathrm{E}$ & & Listvyanka-Tankhoy \\
\hline 7. & $51^{\circ} 35,440 \mathrm{~N}, 105^{\circ} 06,968 \mathrm{E}$ & & 3 km off Tankhoy \\
\hline 8. & $51^{\circ} 46,731 \mathrm{~N}, 105^{\circ} 22,528 \mathrm{E}$ & & Kadilny-Mishikha \\
\hline 9. & $52^{\circ} 20,722 \mathrm{~N}, 106^{\circ} 03,870 \mathrm{E}$ & & Kharauz-Krasny Yar \\
\hline 10. & $52^{\circ} 39,590 \mathrm{~N}, 106^{\circ} 50,978 \mathrm{E}$ & \multirow{8}{*}{$\begin{array}{c}\text { Central } \\
\text { Baikal }\end{array}$} & Anga-Sukhaya \\
\hline 11. & $53^{\circ} 02,955 \mathrm{~N}, 107^{\circ} 25,657 \mathrm{E}$ & & $3 \mathrm{~km}$ off Ukhan \\
\hline 12. & $52^{\circ} 53,630 \mathrm{~N}, 107^{\circ} 31,001 \mathrm{E}$ & & Ukhan-Tonky \\
\hline 13. & $52^{\circ} 44,618 \mathrm{~N}, 107^{\circ} 38,801 \mathrm{E}$ & & 3 km off Tonky \\
\hline 14. & $53^{\circ} 21,278 \mathrm{~N}, 108^{\circ} 13,078 \mathrm{E}$ & & Khoboy-Krestovy \\
\hline 15. & $53^{\circ} 27,245 \mathrm{~N}, 108^{\circ} 44,387 \mathrm{E}$ & & Barguzin Bay \\
\hline 16. & $53^{\circ} 38,063 \mathrm{~N}, 108^{\circ} 07,495 \mathrm{E}$ & & Akademichesky Ridge \\
\hline 17. & $53^{\circ} 42,564 \mathrm{~N}, 109^{\circ} 06,384 \mathrm{E}$ & & Chivyrkuy Bay (5 m depth) \\
\hline 18. & $54^{\circ} 16,860 \mathrm{~N}, 108^{\circ} 44,473 \mathrm{E}$ & \multirow{8}{*}{$\begin{array}{c}\text { Northern } \\
\text { Baikal }\end{array}$} & Zavorotny-Sosnovka \\
\hline 19. & $54^{\circ} 31,829 \mathrm{~N}, 108^{\circ} 42,310 \mathrm{E}$ & & 3 km off Elokhin \\
\hline 20. & $54^{\circ} 27,052 \mathrm{~N}, 109^{\circ} 04,164 \mathrm{E}$ & & Elokhin-Davsha \\
\hline 21. & $54^{\circ} 22,754 \mathrm{~N}, 109^{\circ} 25,314 \mathrm{E}$ & & 3 km off Davsha \\
\hline 22. & $55^{\circ} 20,966 \mathrm{~N}, 109^{\circ} 14,635 \mathrm{E}$ & & 3 km off Baikalsk \\
\hline 23. & $55^{\circ} 19,487 \mathrm{~N}, 109^{\circ} 28,707 \mathrm{E}$ & & Baikalskoye-Turali \\
\hline 24. & $55^{\circ} 17,537 \mathrm{~N}, 109^{\circ} 42,947 \mathrm{E}$ & & 3 km off Turali \\
\hline 25. & $55^{\circ} 42,876 \mathrm{~N}, 109^{\circ} 36,573 \mathrm{E}$ & & 7 km off Nizhneangarsk \\
\hline
\end{tabular}

The samples were fixed in the Lugol solution and then settled (Kuzmin, 1975). For more precise identification of small-cell algae and their scales, we also collected 10-15 ml water samples and filtered them through a Whatman filter with a diameter of $13 \mathrm{~mm}$ and with pore diameter $1 \mu \mathrm{m}$, dried at room temperature, coated with gold and examined on a scanning electron microscope Philips SEM 525M. For transmission electron microscopy (TEM), the sample was put on grids with a diameter of $3 \mathrm{~mm}$ with a formvar film, dried at room temperature and analyzed on a LEO $906 \mathrm{E}$.

The abundance of chrysophytes was estimated from a number of scales found on the filter: very rarely (1) - from 2 to 25 scales; rarely (2) - from 26 to 50 scales; often (3) - from 51-150 scales, and abundantly (4) - over 150 scales.

Potentiometric and Winkler methods were used for measuring $\mathrm{pH}$ and oxygen, respectively (Wetzel \& Likens, 1991). Hydrochemical parameters were measured in the 0 and $25 \mathrm{~m}$ layers, temperature in the surface layer $(0 \mathrm{~m})$ except one site in Chivyrkuy Bay $(7 \mathrm{~m})$. 


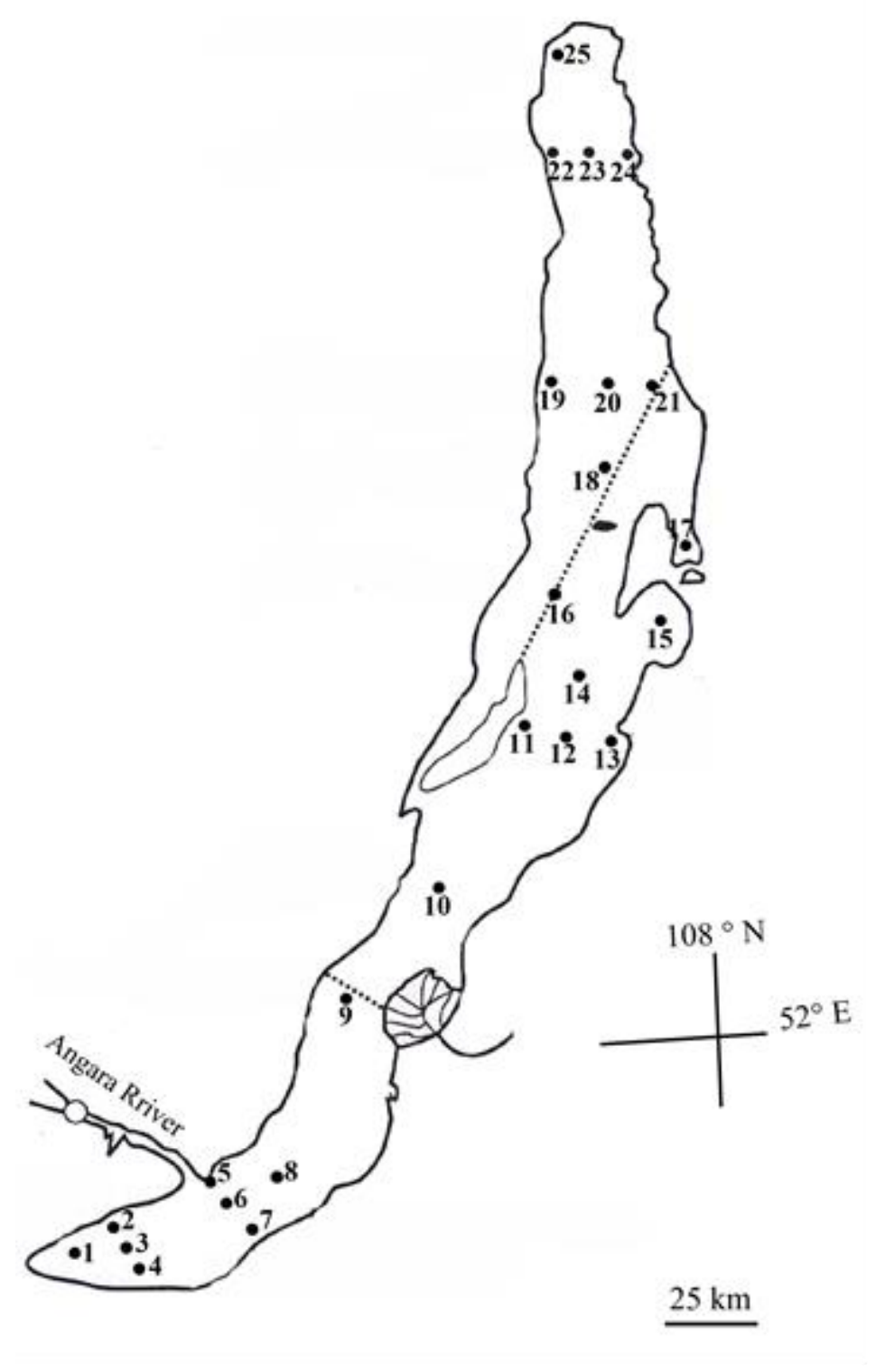

Fig. 1. Sampling scheme. A dashed line shows borders of the lake: Southern, Central and Northern Baikal

\section{Study region}

Water of Lake Baikal is of low mineralization: total ions are approximately $96 \mathrm{mg} / \mathrm{L}$ with the prevalence of bicarbonate ions and calcium. Concentrations of major ions are constant at all depths and around the water area during all seasons (Grachev et al., 2004) except the areas near the mouths of the lake tributaries.

Water conductivity in the lake varies from 108 to $110 \mathrm{mS} / \mathrm{m}$ (Grachev et al., 2004). We should note unique peculiar feature of Lake Baikal - high concentration of oxygen at all depths up to its maximum $1637 \mathrm{~m}$ (Weiss, Carmack, Koropalov, 1991; Shimaraev, Domysheva, Gorbunova, 1996; Grachev et al., 2004). Seasonal variations of oxygen content are observed only in the upper water layer of 100-200 m. Its maximal content (ca. $14.5 \mathrm{mg} / \mathrm{L}$ ) is associated with the underice development of phytoplankton in March-April. After ice breaking, oxygen concentration decreases up to $9 \mathrm{mg} / \mathrm{L}$ and changes insignificantly with depth because of the water warming. During the autumn water cooling, the concentration rises up to the winter maximum. The content of nutrients in Lake Baikal is not high. Their concentrations increase with depth reaching ca. $2 \mathrm{mg} / \mathrm{L}$ of silicon, 0,60 mg/L of nitrate and 0,070 of phosphate in the near-bottom layer (Shimaraev, Domysheva, 2002). Seasonal variations of nutrients are mainly observed in the upper 100-m water layer with their two maxima (January-February and mid June-July) and two minima (April and August-September) (Votintsev, 1961; Grachev et al., 2004).

Hydrochemical parameters during investigations coincided with the data of long-term observations. Water temperature in spring was low $\left(1.8-3.7^{\circ} \mathrm{C}\right)$, and only in May-June it exceeded $6^{\circ} \mathrm{C}$ at two sites $(13$ and 17$)$. In September, water temperature rose to $12-14{ }^{\circ} \mathrm{C}$, however at two sites (6 and 20) it was lower than $10^{\circ} \mathrm{C}$, and at site 23 only $5.21^{\circ} \mathrm{C}$. In spring and autumn, the $\mathrm{pH}$ values varied insignificantly at all sites - about 8 , oxygen concentrations was ca $13 \mathrm{mg} / \mathrm{L}$ in spring and in autumn between 9,70 and $11,86 \mathrm{mg} / \mathrm{L}$. 


\section{Results}

\section{Silica-scaled chrysophytes}

We detected 25 species and intra-specific taxa of silica-scaled chrysophytes in Lake Baikal: Chrysosphaerella - 3, Paraphysomonas - 2, Clathromonas - 1, Spiniferomonas - 7, Mallomonas - 8 and Synura - 4 (Tabs 2, 3; Figs 2-4).

Table 2. List of species and intra-specific taxa of silica-scaled chrysophytes in Lake Baikal observed in May-June. Site numbers correspond to sites in Fig. 1. Abundance was estimated according to the following scale: (3) frequent, (2) rare and (1) very rare

\section{Southern Baikal}

Central Baikal

Northern Baikal

Site number

\begin{tabular}{ll} 
\# & \multicolumn{1}{c}{ Species } \\
1. & Chrysosphaerella baicalensis \\
2. & C. brevispina \\
3. & C. coronacircumspina \\
4. & Paraphysomonas a. \\
5. & P. gladiata \\
6. & Clathromonas takahashii \\
7. & Spiniferomonas abrupta \\
8. & S. bourrellyi \\
9. & S. cornuta \\
10. & S. septispina \\
11. & S. takahashii \\
12. & S. trioralis f. trioralis \\
13. & S. trioralis f. cuspidata \\
14. & Mallomonas acaroides \\
15. & M. alpina \\
16. & M. crassisquama \\
17. & M. mangofera \\
18. & M. striata var. striata \\
19. & M. striata var. getseniae \\
20. & M. tonsurata \\
21. & M. vannigera \\
22. & Synura glabra \\
23. & S. heteropora. \\
24. & S. petersenii \\
25. & S. uvella \\
&
\end{tabular}

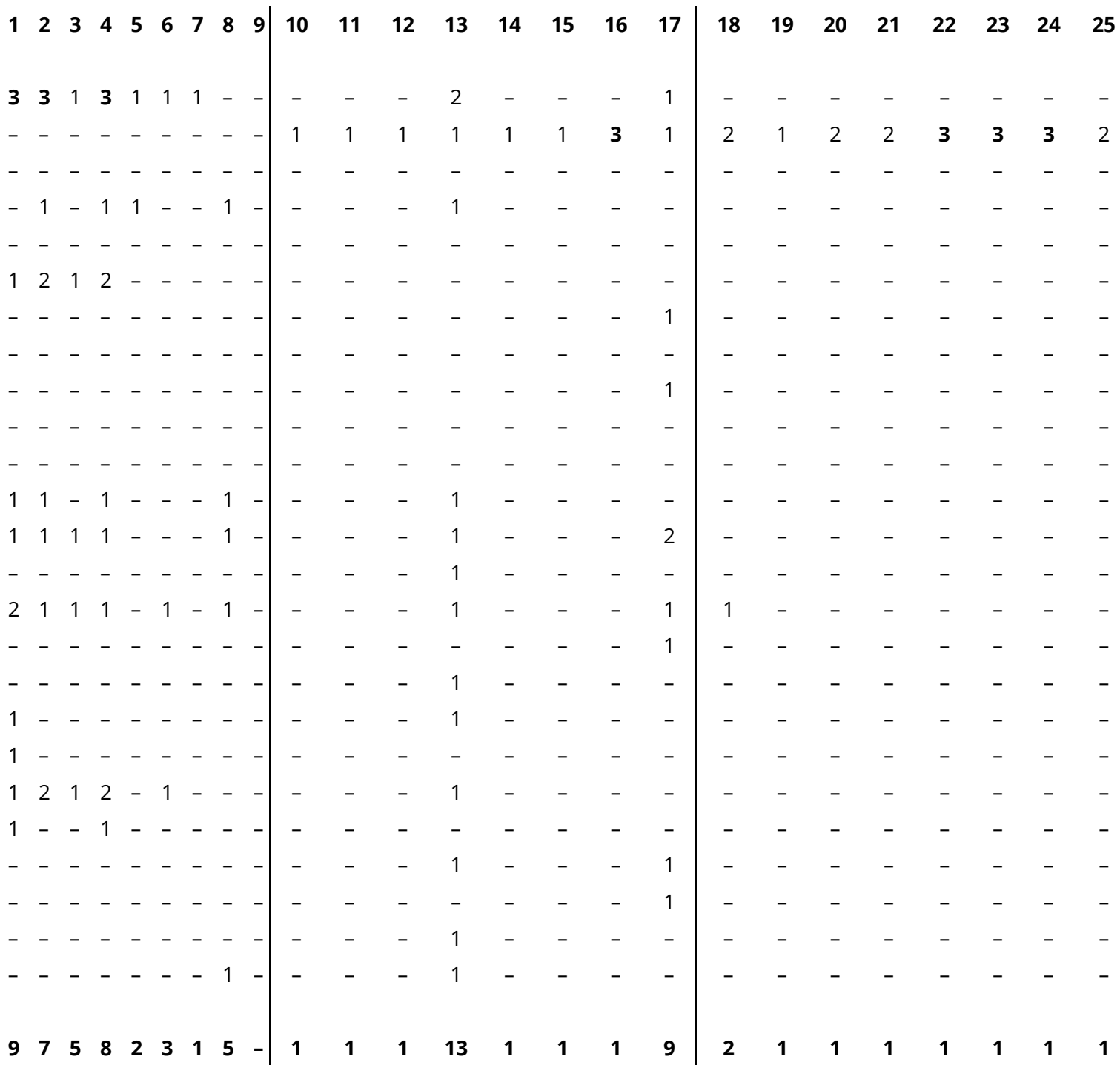

Chrysosphaerella baicalensis Popovskaya (Fig. 2 A, B).

The species was observed predominantly in Southern Baikal with its abundance in May-June at sites 1 and 2. Single specimens were detected in September. In Northern Baikal, it was registered rarely (Tabs 2, 3).

C. brevispina Korshikov (Fig. 2 C, D).

This species was observed often in May-June 2017 predominantly in Central and Northern Baikal (Tab. 2).

C. coronacircumspina Wujek et Kristiansen (Fig. 2 E).

This species was observed in September in Southern and Central Baikal and described for the first time. Maximal abundance was registered in September at sites 12 and 17. Single specimens were found in Northern Baikal (Tab. 3).

Paraphysomonas acuminata acuminata Scoble \& Cavalier-Smith (Fig. 2 F).

This species was described for the first time. Single specimens of the species were registered in May-June predominantly in Southern and Central Baikal (Tab. 2).

P. gladiata Preisig \& Hibberd (Fig. $2 \mathrm{H}$ ). 
This species was described for the first time. Single specimens were detected in the plankton of Northern Baikal in autumn (Tab. 3).

Clathromonas takahashii Cronberg et Kristiansen (Fig. $2 \mathrm{G}$ ).

This species was mentioned for the first time. Maximal abundance was observed in May-June at sites 2 and 4 . It was not registered in Central and Northern Baikal (Tab. 2).

Spiniferomonas abrupta Nielsen (Fig. 3 D, E).

This species was described for the first time in Lake Baikal. Single specimens were detected at site 17 in May-June, and in September at sites 1, 2 and 13 (Tab. 2, 3).

S. bourrellyi Takahashi (Fig. 2 I).

The species was observed in Central Baikal in September at sites 17 and 20 (Tab. 3).

S. cornuta Balonov (Fig. 2 L).

Single specimens of this species were registered for the first time in Lake Baikal in May-June at site 17. In September, the species was observed around the entire water area of the lake (Tab. 2, 3).

S. septispina Nicholls (Fig. 2 J, K).

This species was observed for the first time in Lake Baikal. Maximal abundance was observed in September in Central Baikal at sites 8, 12,13 and 17). In Southern Baikal, it was observed rarely (Tab. 3).

Table 3. List of species and intra-specific taxa of silica-scaled chrysophytes in Lake Baikal observed in September. Site numbers correspond to sites in Fig. 1. Abundance was estimated according to the following scale: (4) abundant, (3) frequent, (2) rare and (1) very rare

\section{Southern Baikal}

\section{Central Baikal}

Site number

\begin{tabular}{|c|c|c|c|c|c|c|c|c|c|c|c|c|c|c|c|c|c|c|c|c|c|c|c|c|c|c|}
\hline \# & Species & 1 & 2 & 3 & 4 & 5 & 6 & 7 & 8 & 9 & 10 & 11 & 12 & 13 & 14 & 15 & 16 & 17 & 18 & 19 & 20 & 21 & 22 & 23 & 24 & 25 \\
\hline 1. & Chrysosphaerella baicalensis & 1 & 1 & - & - & - & - & - & - & - & - & - & - & - & - & - & - & - & - & - & - & - & - & - & - & - \\
\hline 2. & C. brevispina & - & - & - & - & - & - & - & - & - & - & - & - & - & - & - & - & - & - & - & - & - & - & - & - & - \\
\hline 3. & C. coronacircumspina & 2 & 2 & 1 & 2 & 2 & 2 & 2 & 2 & 2 & 2 & 1 & 3 & 2 & 2 & - & 1 & 3 & 1 & 1 & 2 & 1 & - & 1 & - & - \\
\hline 4. & Paraphysomonas a. acuminata & - & - & - & - & - & - & - & - & - & - & - & - & - & - & - & - & - & - & - & - & - & - & - & - & - \\
\hline 5. & P. gladiata & - & - & - & - & - & - & - & - & - & - & - & - & - & - & - & - & - & - & 1 & 1 & 1 & - & - & - & - \\
\hline 6. & Clathromonas takahashii & - & - & - & - & - & - & - & - & - & - & - & - & - & - & - & - & - & - & - & - & - & - & - & - & - \\
\hline 7. & Spiniferomonas abrupta & 2 & 2 & - & - & - & - & - & - & - & - & - & - & 2 & - & - & - & - & - & - & - & - & - & - & - & - \\
\hline 8. & S. bourrellyi & - & - & - & - & - & - & - & - & - & - & - & - & - & - & - & - & 2 & - & - & 2 & - & - & - & - & - \\
\hline 9. & S. cornuta & 2 & 2 & 2 & - & 2 & 2 & - & 2 & - & 2 & - & 2 & 2 & - & - & - & 2 & - & - & - & 1 & - & 1 & - & - \\
\hline 10. & S. septispina & - & - & - & - & - & - & - & 2 & - & - & - & 2 & 2 & - & - & - & 2 & - & - & - & - & - & - & - & - \\
\hline 11. & S. takahashii & - & - & - & - & - & - & - & - & - & 1 & - & - & - & - & - & 1 & - & - & - & - & - & - & - & - & - \\
\hline 12. & S. trioralis f. trioralis & 4 & 4 & 4 & 3 & 3 & 4 & 2 & 4 & 3 & 3 & 1 & 3 & 4 & 2 & 1 & 1 & 3 & 3 & 1 & 3 & 1 & 1 & 1 & - & 1 \\
\hline 13. & S. trioralis f. cuspidata & 4 & 4 & 4 & 3 & 3 & 4 & 3 & 4 & 4 & 3 & 2 & 3 & 4 & 2 & 1 & 1 & 3 & 3 & 1 & 3 & 1 & 1 & 1 & 1 & - \\
\hline 14. & Mallomonas acaroides & - & - & - & - & - & 2 & - & - & - & - & 2 & - & - & 2 & 3 & - & 3 & 1 & 1 & - & 1 & - & - & - & - \\
\hline 15. & M. alpina & 1 & 2 & - & - & - & 1 & - & 1 & - & - & - & - & - & - & - & - & - & - & - & - & - & - & - & - & - \\
\hline 16. & M. crassisquama & - & - & - & - & - & - & - & - & - & - & - & - & - & - & - & - & 1 & - & - & - & - & - & - & - & - \\
\hline 17. & M. mangofera & - & - & - & - & - & - & - & - & - & - & - & - & - & - & - & - & - & - & - & - & - & - & - & - & - \\
\hline 18. & M. striata var. striata & - & - & - & - & - & - & - & - & - & - & - & - & - & - & - & - & - & - & - & - & - & - & - & - & - \\
\hline 19. & M. striata var. getseniae & - & - & - & - & - & - & - & - & - & - & - & - & - & - & - & - & - & - & - & - & - & - & - & - & - \\
\hline 20. & M. tonsurata & - & - & - & - & - & 1 & - & - & - & - & - & 2 & - & - & - & - & - & - & - & - & - & - & - & - & - \\
\hline 21. & M. vannigera & - & - & - & - & - & - & - & - & - & - & - & - & - & - & - & - & - & - & - & - & - & - & - & - & - \\
\hline 22. & Synura glabra & - & - & - & - & - & - & - & - & - & - & - & - & - & - & - & - & - & - & - & - & - & - & - & - & - \\
\hline 23. & S. heteropora & - & - & - & - & - & - & - & - & - & - & - & - & - & - & - & - & - & - & - & - & - & - & - & - & - \\
\hline 24. & S. petersenii & - & - & - & - & - & - & - & - & - & - & - & - & - & - & - & - & - & - & - & - & - & - & - & - & - \\
\hline 25. & S. uvella & - & - & - & - & - & - & - & - & - & - & - & - & - & - & - & - & - & - & - & - & - & - & - & - & - \\
\hline & Total taxa & 7 & 7 & 4 & 3 & 4 & 7 & 3 & 6 & 3 & 5 & 4 & 6 & 6 & 4 & 3 & 4 & 7 & 4 & 5 & 5 & 6 & 2 & 4 & 1 & 1 \\
\hline
\end{tabular}




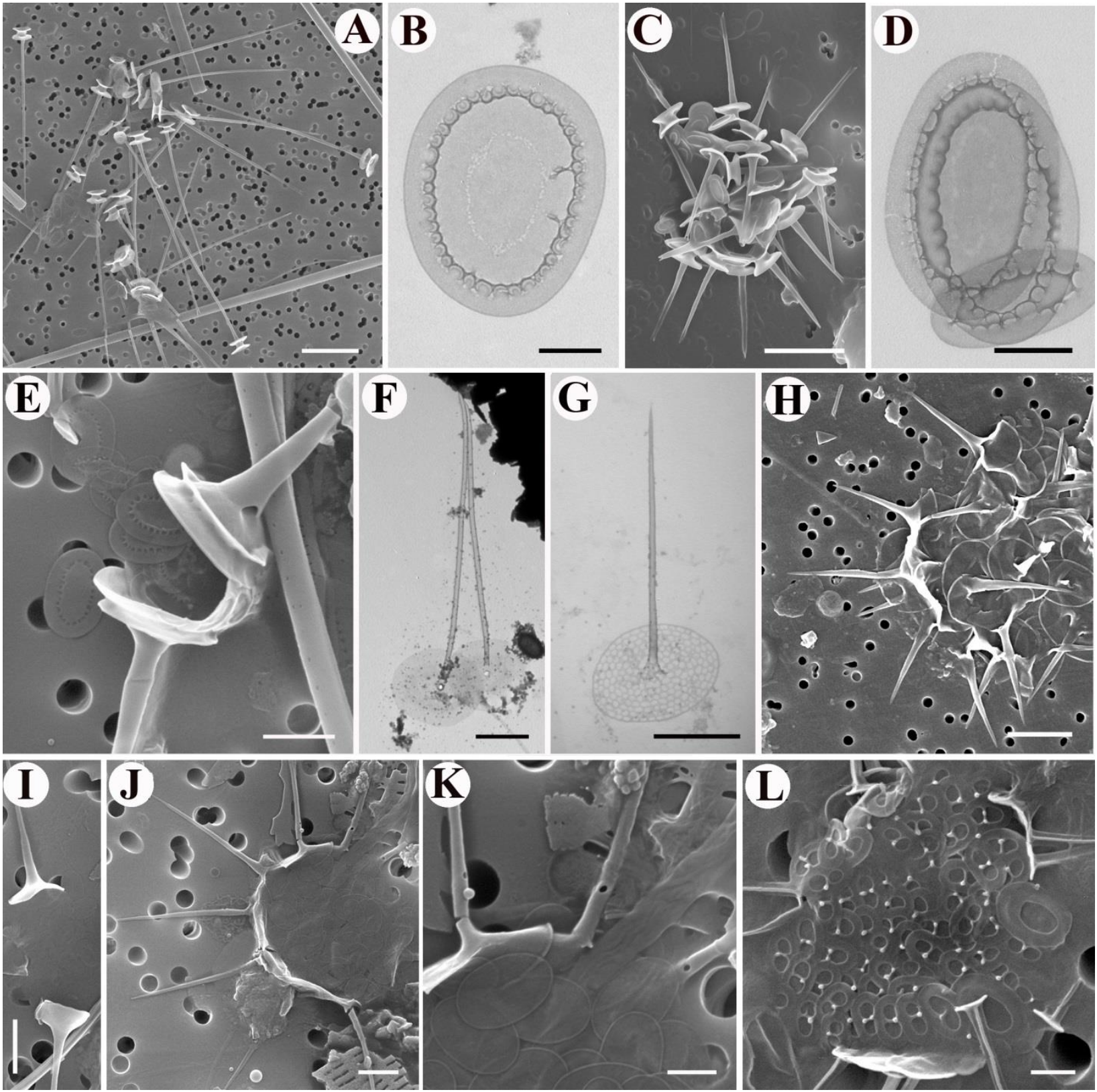

Fig. 2. SEM (A, C, E, H-L), TEM (B, D, F, G). Scales and spines of silica-scaled chrysophytes of Lake Baikal:

A, B - Chrysosphaerella baicalensis; C, D - C. brevispina; E - C. coronacircumspina; F - Paraphysomonas acuminata acuminata; G - Clathromonas takahashii; H - P. gladiata; I - Spiniferomonas bourrellyi; J, K - S. septispina; L - S. cornuta. Scale bars: B $0.5 \mathrm{~nm} ; \mathrm{D}, \mathrm{F}-\mathrm{H}, \mathrm{K}, \mathrm{L}-1 \mu \mathrm{m} ; \mathrm{E}, \mathrm{I}, \mathrm{J}-2 \mu \mathrm{m} ; \mathrm{A}, \mathrm{C}-10 \mu \mathrm{m}$

\section{S. takahashii Nicholls (Fig. 3 F).}

This species was registered for the first time in Russia. Single specimens were found only in September in Central Baikal (sites 10 and 16) (Tab. 3).

S. trioralis f. trioralis Takahashi (Fig. 3 C).

The form was registered for the first time in Lake Baikal ubiquitously around the entire water area of the lake. Maximal abundance of this species was observed in Southern and Central Baikal in September. However, in Northern Baikal it was found rarely (Tabs 2, 3).

\section{S. trioralis f. cuspidata Balonov (Fig. 3 A, B).}

The form was registered ubiquitously around the entire water area of the lake. Maximal abundance of this species was observed in Southern and Central Baikal in September. However, in Northern Baikal it was found rarely (Tabs 2, 3).

Mallomonas acaroides Perty (Fig. $3 \mathrm{I}, \mathrm{J}$ ).

The species was observed predominantly in September with its maximal abundance in Central Baikal at sites 15 and 17 (Tab. 3).

M. alpina Pascher \& Ruttner (Fig. 3 G, K).

The species was registered in Southern and Central Baikal in May-June and September and rarely in Northern Baikal (Tabs 2, 3). 
Bessudova, A.Yu., et al. (2017). Silica-scaled chrysophytes.... Acta Biologica Sibirica, 2017, 3(3), 47-56
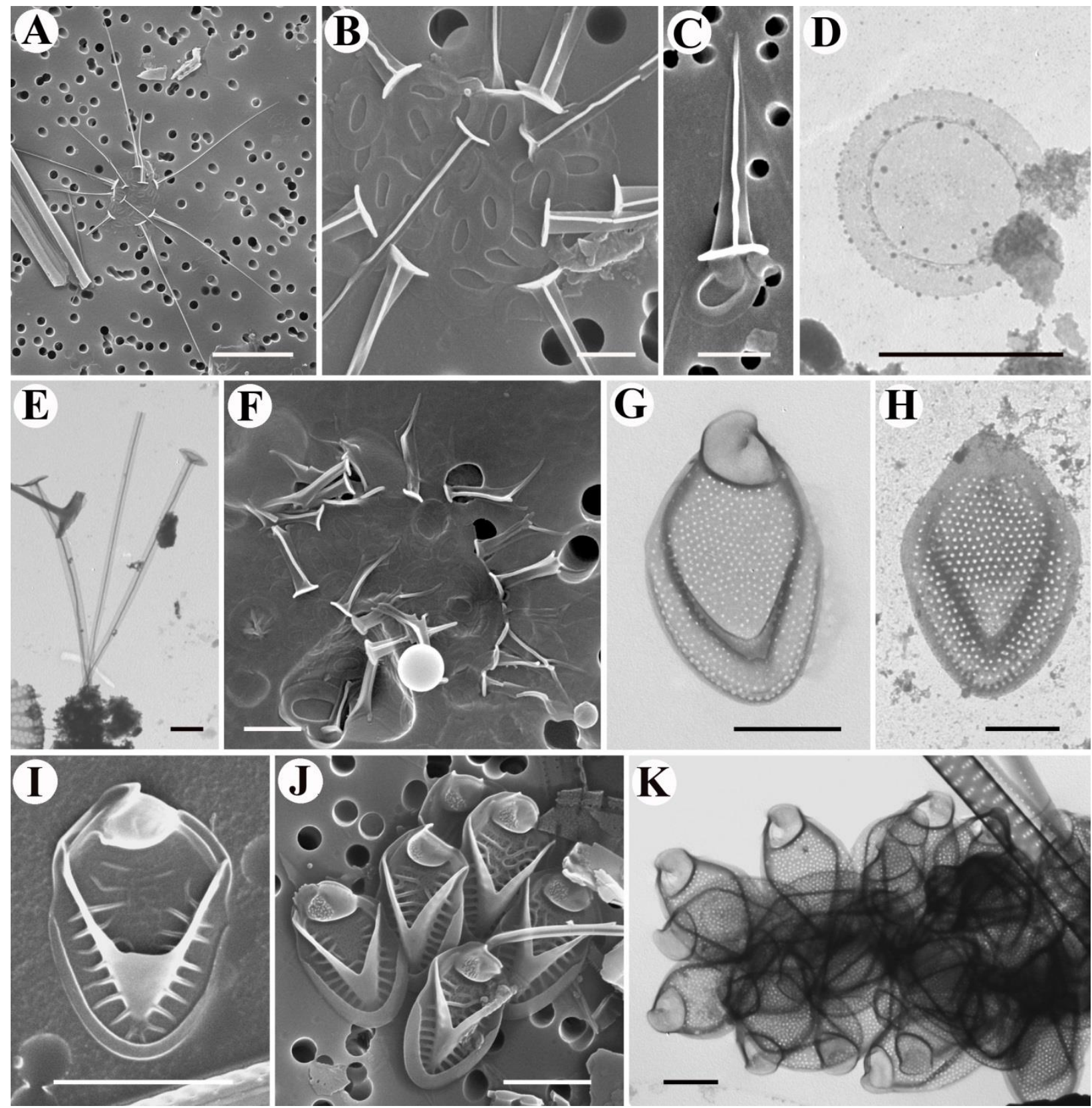

Fig. 3. SEM (A-C, F, I, J), TEM (D, E, G, H, K). Scales and spines of silica-scaled chrysophytes from Lake Baikal:

A, B - S. trioralis f. cuspidata; C - S. trioralis f. trioralis; D, E - S. abrubta; F - S. takahashii; G, L - Mallomonas alpina; H - M. tonsurata; J, K - M. acaroides. Scale bars: B-E, H - $1 \mu \mathrm{m} ; \mathrm{F}, \mathrm{G}, \mathrm{K}-2 \mu \mathrm{m} ; \mathrm{I}, \mathrm{J}-4 \mu \mathrm{m} ; \mathrm{A}-10 \mu \mathrm{m}$.

\section{S. takahashii Nicholls (Fig. 3 F).}

This species was registered for the first time in Russia. Single specimens were found only in September in Central Baikal (sites 10 and 16) (Tab. 3).

S. trioralis f. trioralis Takahashi (Fig. 3 C).

The form was registered for the first time in Lake Baikal ubiquitously around the entire water area of the lake. Maximal abundance of this species was observed in Southern and Central Baikal in September. However, in Northern Baikal it was found rarely (Tabs 2, 3).

\section{S. trioralis f. cuspidata Balonov (Fig. 3 A, B).}

The form was registered ubiquitously around the entire water area of the lake. Maximal abundance of this species was observed in Southern and Central Baikal in September. However, in Northern Baikal it was found rarely (Tabs 2, 3).

Mallomonas acaroides Perty (Fig. $3 \mathrm{I}, \mathrm{J}$ ).

The species was observed predominantly in September with its maximal abundance in Central Baikal at sites 15 and 17 (Tab. 3).

M. alpina Pascher \& Ruttner (Fig. $3 \mathrm{G}, \mathrm{K}$ ).

The species was registered in Southern and Central Baikal in May-June and September and rarely in Northern Baikal (Tabs 2, 3).

M. crassisquama (Asmund) Fott (Fig. 4 A). 
Bessudova, A.Yu., et al. (2017). Silica-scaled chrysophytes.... Acta Biologica Sibirica, 2017, 3(3), 47-56

Single specimens of the species were observed only in Central Baikal (site 17) in May-June and September (Tabs 2, 3).

M. mangofera K.Harris \& D.E.Bradley (Fig. 4 B).

This species was described for Lake Baikal for the first time. Single specimens were observed in Southern Baikal (site 13) (Tab. 2).

M. striata var. striata Asmund (Fig. 4 D).

The variation was registered rarely in Southern and Central Baikal in May-June (Tab. 2).

M. striata var. getseniae Voloshko (Fig. 4 C).

The variation was observed rarely in Southern Baikal in May-June. Earlier, it was named as M. striata var. striata (Vorobyeva et al., 1992) (Tab. 2).

M. tonsurata Teiling (Fig. $3 \mathrm{H}$ ).

The species was detected in May-June and in September in Southern and Central Baikal. The maximal abundance was registered at sites 2 and 4. In Northern Baikal, it was observed rarely (Tabs 2, 3).

M. vannigera Asmund (Fig. 4 E, F).

The species was observed rarely in May-June in Southern and Central Baikal (Tab. 2).

Synura glabra Korshikov (Fig. 4 G).

Single specimens of this species were observed for the first time in Central Baikal in May-June at site 17 (Tab. 2).

S. heteropora Skaloud, Skaloudová \& Procházková in Skaloud et al. (Fig. 4 I, J).

Single specimens of this species were observed for the first time in Central Baikal at sites 13 and 17 in May-June (Tab. 2).

S. petersenii Korshikov (Fig. $4 \mathrm{~K}, \mathrm{~L}$ ).

Single specimens of this species were registered for the first time in Central Baikal in May-June at site 13 (Tab. 2).

S. uvella Ehrenberg (Fig. $4 \mathrm{H}$ ).

This species was observed rarely in Southern and Central Baikal in May-June at site 17 (Tab. 2).

M. caudata, P. vestita and Chrysosphaerella longispina observed in earlier studies were not registered in this investigation. We think that these species were observed with light microscopy probably by mistake (Meyer, 1030; Kozhova, 1959).

\section{Discussion}

\section{Spatial distribution and seasonal dynamics of silica-scaled chrysophytes in Lake Baikal}

The highest diversity of silica-scaled chrysophytes was observed in the southern and central basins of Lake Baikal. In spring and summer, their abundance is low due to the dominance of large diatoms in this period as well as to low water temperature that limits their growth. The following species develop intensely in spring and summer: Chrysosphaerella baicalensis, C. brevispina, Clathromonas takahashii, Mallomonas alpina and M. tonsurata. These species are observed more often as a whole cell. It should be noted that C. brevispina was observed only in May-June of 2017, whereas C. baicalensis was detected only in May-June of 2016 (Tab. 2).

The peak of chrysophyte growth in Lake Baikal is observed in autumn (Tab. 3) when vegetation of large diatoms decreases and water temperature is higher than in spring. In September, we observed C. coronacircumspina, S. bourrellyi, S. septispina, S. cornuta and M. acaroides with the dominance of S. trioralis f. trioralis and S. trioralis f. cuspidata.

Studying samples taken on filters during the cruise around Lake Baikal in september 2016, 3 morphotypes were identified by scales to species among 20 stomatocyst morphotypes: Stomatocyst 156 Zeeb \& Smol, 1993 Chrysosphaerella coronacircumspina; Stomatocyst 223 Firsova \& Likhoshway, 2006 - Spiniferomonas trioralis; Stomatocyst 302 Firsova, 2006 - Spiniferomonas septispina (Firsova, Bessudova, Likhoshway, 2017).

In this study we demonstrated that in Lake Baikal vegetative cells and silicious scales are more frequent than dormant stomatocysts. Several cells of these species had not had stomatocyst; it points to the fact that september could be a time when the dormant phases of these species are being formed.

\section{Biogeographic distribution}

The following rare taxa or taxa with limited distribution were observed in Lake Baikal: C. takahashii, Spiniferompnas abrupta, S. septispina, S. takahashii, P. a. acuminata, M. striata var. getseniae.

C. takahashii were observed earlier in Vashutkiny and Kharbeiskiye lakes (Siver et al., 2005), in Lake Ladoga (Voloshko, Gavrilova, Gromov, 2002) and in Labynkyr and Vorota lakes (Yakutia) (Bessudova et al., 2016). Spiniferompnas abrupta was registered in Russia only in these Yakutian lakes (Bessudova et al., 2016). S. septispina was observed earlier in Russia in the lakes of the Polar Urals (Voloshko, 2010). S. takahashii is a rare species with scattered distribution. It was observed in North America (Siver, 1988; Siver, Wujek, 1999) and North Europe (Nemcová et al., 2016). M. striata var. getseniae is considered to be an endemic species in the north of Russia (Voloshko, 2013). It was also found on the Taymyr Peninsula (Kristiansen, Duwell, Wegeberg, 1997) and in aquatic ecosystems of the Polar Urals (Voloshko, 2010).

\section{Specific morphology of some chrysophytes of Lake Baikal}

During our investigations, we have found a number of morphological peculiar characteristics of chrysophytes from Lake Baikal. For example, M. acaroides possesses two types of scales: the first type is scales whose morphology is characteristic of $M$. acaroides (the scales are wider and relatively large) (Fig. 3 I); the scales of the second type are of a 
Bessudova, A.Yu., et al. (2017). Silica-scaled chrysophytes.... Acta Biologica Sibirica, 2017, 3(3), 47-56

narrower elongated form with an acute V-rib, thicker ribs on the posterior flange and rough large-pore reticulum on the shield like in M. crassisquama (Fig. $3 \mathrm{~J}$ ). It is likely that both $M$. acaroides and $M$. striata are changeable species. Earlier, Kristiansen et al. (1995) described in detail the scales with similar morphology from the volcanic lake Pingo (Greenland). The author also cited a number of references in which there were microphotographs of a similar morphotype in samples collected from other regions of the world (Fott, 1962; Kristiansen, 1979; Wee, 1982; Kristiansen, Tong, 1989; Kristiansen, Tong, Olrik, 1990). In Russia, scales of M. acaroides with similar morphology were found in the Lower Yenisei basin (Bessudova et al., 2016).

All cells of Spiniferompnas cornuta found in Lake Baikal have 3 types of scales: (1) large with one lacuna, (2) with two lacunas and two processes and (3) two lacunas and one process. The cells of $S$. cornuta have two types of scales (Siver, 1988; Voloshko, 2013).

Chrysosphaerella baicalensis is similar to C. brevispina but different in some morphological characteristics. The spine length in C. baicalensis can reach $35 \mu \mathrm{m}$, whereas that in C. brevispina from Lake Baikal is 11-15 $\mu \mathrm{m}$. Basal plates of spines in C. baicalensis are of similar diameter. The thickness of a spine is the same along its entire length contrary to $C$. brevispina whose spine base is a little wider than its apex.

Hence, according to our data, Lake Baikal houses 25 species and intra-specific taxa of silica-scaled chrysophytes. These are mainly widespread taxa. Their highest diversity was observed in the southern and central basins of Lake Baikal. Maximal abundance and species diversity was observed in autumn.

\section{Acknowledgements}

This work was supported by the FASO project \# 0345-2016-0001.

\section{References}

Antipova, N.L. (1969). Seasonal and annual changes in phytoplankton of Lake Baikal: Ph.D. thesis. Irkutsk (in Russian). Antipova, N.L. (1974). Annual variability in phytoplankton of Lake Baikal in Bolshiye Koty for 1960-1970. Productivity of Lake Baikal and anthropogenic changes of its nature. Irkutsk: Irkutsk State University, 75-84 (in Russian).

Asmund, B., Kristiansen, J. (1986). The genus Mallomonas (Chrysophyceae). Opera Botanica, 85, 1-128.

Baikal. Atlas. (1993). In: Galazy G.I. (Ed.). Omsk: Cartographic Factory (in Russian).

Atlas and Key of Baikal Pelagic bionts (with brief profiles of their ecology), 1995 - In: Timoshkin, O.A., Mazepova, G.F., Melnik, N.G. et al. (Eds). Novosibirsk: Nauka (in Russian).

Balonov, I.M. (1980). About Mallomonas vannigera Asmund, species is new to USSR flora. Proceedings of Institute of Inland Water Biology USSR, 47, 8-15 (in Russian).

Bessudova, A.Yu., Tomberg, I.V., Firsova, A.D., Kopyrina, L.I., Likhoshway, Ye.V. (2016). Silica-scaled chrysophytes in lakes Labynkyr and Vorota, Yakutia, Russia. $9^{\text {th }}$ International Chrysophyte Symposium ICS9. Japan, Yamagata, p. 27.

Bessudova, A.Yu., Firsova, A.D., Sorokovikova, L.M., Tomberg, I.V. (2016). Silica-scaled chrysophytes of the Lower Yenisei basin and bays of the Kara Sea with autecology elements. Irkutsk: Institute of Geografy (in Russian).

Izmestyeva, L.R., Kozhova, O.M. (1988). Structure and succession of phytoplankton. Long-term forecast of ecosystem state. Novosibirsk: Nauka, 97-129.

Firsova, A.D., Bessudova, A.Yu., Likhoshway, Ye.V. (2017). New data of chrysophycean stomatocysts from Lake Baikal. Acta Biologica Sibirica, 2017 (in press).

Fott, B. (1962). Taxonomy of Mallomonas based on electron microscopy of scales. Preslia, 34, 69-84.

Grachev, M.A., Domysheva, V.M., Khodzher, T.V., Korovyakova, I.V., Golobokova, L.P., Pogodaeva, T.V. et al. (2004). Deep water of Lake Baikal as a natural standard of fresh water. Chemistry in View of Sustainable Development, 12, 417429 (in Russian).

Kozhova, O.M. (1959). A systematic list of planktonic algae of Lake Baikal and some data on biology of mass forms. News of Siberian Branch of the USSR Academy of Sciences, 10, 112-124 (in Russian).

Kristiansen, J. (1979). Observations on some Chrysophyceae from North Wales. British Phycological Journal, 41, 231241.

Kristiansen, J., Tong, D. (1989). Studies on silica-scaled chrysophytes from Wuhang, Hangzhou and Beijing, P.R. China. Nova Hedwigia, 49, 183-202.

Kristiansen, J., Tong, D, Olrik, K. (1990). Silica-scaled chrysophytes from Korea, a preliminary study. Nordic Journal of Botany, 9, 685-691.

Kristiansen, J., Wilken, L.R., Jürgensen, T. (1995). A bloom of Mallomonas acaroides, a silica-scaled chrysophyte, in the crater pond of a pingo, northwest Greenland. Polar Biology, 15, 319-324.

Kristiansen, J., Duwell, L., Wegeberg, S. (1997). Silica-scaled chrysophytes from the Taymyr peninsula, Northern Siberia. Nova Hedwigia, 65, 337-351.

Kuzmin, G.V. (1975). Phytoplankton. Species composition and abundance. Methods for studying biogeocenoses of inland water bodies. Moscow: Nauka, 73-87 (in Russian).

Meyer, K.I. (1930). Introduction to algal flora of Lake Baikal. Newsletter of Moscow Society of Naturalists, a New Series, 39, 3-4 (in Russian). 
Bessudova, A.Yu., et al. (2017). Silica-scaled chrysophytes.... Acta Biologica Sibirica, 2017, 3(3), 47-56

Němcová, Y., Martin, P., Škaloudová, M., Neustupa, J. (2016). Silica-scaled chrysophytes (Stramenopiles, Ochrophyta) along a salinity gradient: a case study from the Gulf of Bothnia western shore (Northern Europe). Hydrobiologia, 764, 187197.

Pla, S. (2001). Chrysophycean cysts from Pyrenees. Biblioteka Phycologica

Popovskaya, G.I. (1981). A new species of the genus Chrysosphaerella in plankton of Lake Baikal. News on Systematics of Lower Plants. Leningrad: Nauka, 8, 9-12 (in Russian).

Popovskaya, G.I., Genkal, S.I., Likhoshway, Ye.V. (2016). Diatoms of the Plankton of Lake Baikal. Atlas and Key. In: Trifonova I.S., Grawford R.M. (Eds). Novosibirsk: Nauka.

Shimaraev, M.N., Domysheva, V.M., Gorbunova, L.A. (1996). On oxygen dynamics in Lake Baikal during spring mixing. Doklady Akademii Nauk, 347, 6, 814-817 (in Russian).

Shimaraev, M.N., Domysheva, V.M. (2002). On dynamics of dissolved silicon concentrations in Lake Baikal. Doklady Akademii Nauk, 387, 4, 541-544 (in Russian).

Siver, P.A. (1988). The distribution and ecology of Spiniferomonas (Chrysophyceae) in Connecticut (USA). Nordic Journal of Botany, 8, 205-212.

Siver, P.A., Wujek, D.E. (1999). Scaled Chrysophyceae and Synurophyceae from Florida, U.S.A.: VI. Preliminary observations on the flora from waterbodies in the Ocala National Forest. Nova Hedwigia, 68, 1-2, 75-92.

Siver, P.A., Voloshko, L.N., Gavrilova, O.V., Getsen, M.V. (2005). The scaled chrysophyte flora of the Bolshezemelskaya tundra. Nova Hedwigia Beihef, 128, 125-150.

Voloshko, L.N., Gavrilova, O.V., Gromov, B.V. (2002). Diversity of Chrysophyta (Paraphysomonadaceae, Mallomonadaceae, Synuraceae) in Lake Ladoga. Phycology, 12, 2, 25-35 (in Russian).

Voloshko, L.N. (2010). The chrysophycean algae from glacial lakes of Polar Ural (Russia). Nova Hedwigia Beihef, 136, 191-211.

Voloshko, L.N. (2013). Species of the genus Spiniferomonas (Chrysophyceae, Paraphysomonadaceae) in waterbodies of North Russia. Botanical Journal, 98, 7, 848-867 (in Russian).

Voloshko, L.N. (2016). Chrysophytes of North Russia. Genus Chrysosphaerella. Botanical Journal, 101, 7, 753-776 (in Russian).

Vorobyova, S.S., Bondarenko, N.A., Karpova, S.A., Pomazkina, G.V., Tanichev, A.I. (1992). To studies of Chrysophyta species composition of Lake Baikal. Algologia, 2, 3, 68-72 (in Russian).

Votintsev, K.K. (1961). Hydrochemistry of Lake Baikal. Proceedings of Baikal Limnological Station. Moscow: Publishing House USSR AS, 20 (in Russian).

Votintsev, K.K., Meshcheryakova, A.I., Popovskaya, G.I. (1975). Cycle of organic matter in Lake Baikal. Novosibirsk: Nauka (in Russian).

Wee, J.L. (1982). Studies on the Synuraceae (Chrysophyceae) of lowa. Bibliotheca Phycologica, Band, 62, 1-183.

Weiss, R.F., Carmack, E.C., Koropalov, V.M. (1991). Deep-water renewal and biological production in Lake Baikal. Nature, 349, 665-669.

Wetzwl, R.G., Likens, G.E. (1991). Limnological Analyses. New York: Springer-Verlag, 69-80.

Zagorenko, G.F., Kaplina, G.S. (1988). Composition of the pelagic area in Southern Baikal near Bolshiye Koty. Novelty in Studies of Flora and Fauna of Lake Baikal and Its Basin. Irkutsk: Publishing House of Irkutsk State University, 26-32 (in Russian).

\section{Citation:}

Bessudova, A.Yu., Domysheva, V.M. Firsova, A.D. Likhoshway, Y.V. (2017). Silica-scaled chrysophytes of Lake Baikal. Acta Biologica Sibirica, 3 (3), 47-56.

Submitted: 27.06.2016. Accepted: 23.08.2017

cross $r$ ref $\underline{\text { http://dx.doi.org/10.14258/abs.v3i3.3615 }}$

(C) 2017 by the authors. Submitted for possible open access publication under the terms and conditions of the Creative Commons Attribution (CC BY) license (http://creativecommons.org/licenses/by/4.0/). 